\title{
The Role of Chinese Modern Distance Education in Lifelong Learning
}

\section{Lingling DONG}

Dalian university of technology school of distance and continuing education, Dalian, Liaoning, 116011, China

\begin{abstract}
With the forthcoming of knowledge economy and the integration of world cultures, fundamental changes have taken place in production mode and people's life. Lifelong learning has become an inevitable choice. Modern distance education has been introduced into the system of lifelong learning in EU, Australia and America. In those areas, laws and policies have been enacted, research programs have been launched, relevant standards and norms have been formulated, resource sharing service has been activated and some restrictions are imposed on educational institutes. In China, modern distance education plays an important role in the system of lifelong learning.
\end{abstract}

KEYWORD: modern distance education; lifelong learning; role

Lifelong learning refers to the process during which an individual keeps learning all his life. It means that everyone is entitled to receiving education or participating in learning and that everyone should have equal education opportunity. Recently, both in developed countries and developing countries, modern distance education has made rapid progress. The reasons for the progress lie in the following aspects: increasing education opportunities, reducing education costs, promoting education popularization and meeting the needs for lifelong learning. Faced with imbalanced economic development and the scarcity of high quality educational resources, the importance of lifelong learning in promoting modern distance education is being increasingly highlighted. On 31, Jan, 2008, State Councilor Chen Zhili, in his Enhancing the Importance of Modern Distance Education in Developing A Country rich in Human Resource, pointed out that it is important to give full play to modern distance education so as to promote its significance in developing a country where every one learns and is committed to lifelong learning, minimize educational gap and promote educational equality.

\section{SUPPORT FROM EDUCATIONAL THEORY AND CONCEPTS}

Concept of lifelong learning is to make more and more people realize: The purpose of learning is not only to acquire knowledge, more important is to learn how to learn; The purpose of education is not only to impart knowledge, more important is to develop the ability of learners; Function of education is not only preserved, disseminate, develop existing knowledge, more important is the creation of new knowledge, new ideas and new values, so that all aspects of society can provide equal opportunities and conditions for learning members of society, the creation of open educational resources system.

Modern Distance Education builds a theoretical foundation for lifelong learning depending on its advanced educational concepts and ideas that is a major change in thinking and theories for traditional education. Specifically speaking, these changes are as follows: the change from teacher's "teaching" focused to learner's "learning" focused; the change from collective class teaching to individual selfstudy; the change from mechanical, passive learning to research, collaborative and flexible active learning; the teaching resources change from single media to a variety of medias; the change from the pursuit of knowledge simply to improvement of their comprehensive qualities and capabilities. All of these changes are fully reflected the new concept of lifelong learning.

Chinese modern distance education explores actively in changing educational concepts, building personnel training mode and other aspects and makes rapid development in education ideas and concepts changes. A survey shows that "More than $90 \%$ of our students and their parents have an urgent need for low-cost, high-quality and sustainably 
developed excellent education, more than 75 percent of the workers are continuously trained in different degrees, more than $50 \%$ of business managers need professional learning and training, $45 \%$ of young people are trained and learning foreign languages." Meanwhile, IT courses have entered deeply into the towns, rural areas. The education and training become products and services. The profit-getting network companies have entered the modern distance education network market and actively participate in the competition.Therefore, in a word the shift in people's learning concepts, the improvement of initiative, a good development and broad social base of modern distance education are in favor of the construction and the formation of lifelong learning.

\section{SUPPORT FROM TECHNICAL MEANS AND ENVIRONMENT}

The development of science and the advanced technology have given access to a variety ways of learning. Take our modern long-distance education for example, it enables people to get education regardless of the limitation of time and space, therefore, lifelong education could be achieved. The modern long-distance education is based on the establishment of cyber world, in which people personalized their self-learning by availing themselves of the hi-tech educational means of email, bulletin board system, virtual lab and electronic library with no regard to time and place.Besides,the relative cheaper tuition compared with traditional education contributes greatly to the popularity of life-long education. With the adoption of resourceful modern long-distance learning, learners are more likely to be involved and adapt to the ever-changing social setting, being equipped with the skills needed.

In addition, the application of modern technology of education has helped the learners gain real subjectivity. In this modern long-distance education setting, teachers and students are in a state of being detached or semi-detached, the role of educators has shifted from a manipulator in traditional education to a source of education available in long-distance education, thus becoming a component in multimedia education, while learners have become to be "selector and user" rather than "object of education" which they used to be. The materials adopted into multi-media long-distance education are featured in personalized study plans, paying special attention to the needs and characteristics of individual learners and trying to meet the diverse needs of learners in various levels, and thereby education caters to the specific demands of learners on time and location, to the demands of human physical health, ageing degree and cognitive characteristics on ways and time of presentation; to the demands of learning materials on virtual study environment; to the demands of study contents, study process on the selection and integrated application of learning media; to the demands of human cognition、 ability and emotion development on distance education forms and implementation; and to the demands of an overall evaluation of study effect, etc.

In the $17^{\text {th }}$ National Congress of CPC, Hu Jintao put forward the policy of "Promoting long-distance education and continuing education in the constructing of a Lifelong-Learning-for-All society". Our country has not only made policies in favor of the development of modern long-distance education, also a great amount of capital and human resource have been invested into building a supportive educational environment for long-distance education. Up to now, the Ministry of Education of the PRC has launched the projects of "New Century Network Course", "State-class Competitive course" and "Digital Learning Center in On-line Education", all of which are functioning well in pushing forward the integration and sharing of the best educational resources. The speed-up process of the backbone net work of CERNET has been finished, a relatively perfect network education system has taken shape, a reform of digitizing satellite television has also been successfully completed and put into use. All these efforts have offered a powerful technical support for building up a lifelong learning system.

\section{SUPPORT FROM COLLEGE MODEL AND SERVICE SYSTEM}

Since the education idea of the lifelong learning system is human-oriented and it aims to offer continuous assistance in the learning process throughout people's life, it is necessary to improve the connection and communication among various forms of education nowadays. Continuing education cannot be simplified as merely academic credential education or non-academic vocational training. The function of continuing education should be emphasized, and the practice in corresponding institutions should be simplified as well. Bridges are required to promote the communication among various forms of education at different levels, including pre-school education, fundamental education, higher education, vocational education and continuing education. Cooperation between formal and informal education as well as the participation of college, family, community and business all contribute to the integration of education resources and lead to effective utilization. In this way, people are free to cultivate themselves by learning continuously via different channels as long as they want to. The connection and communication among various education forms are a must to make the system possible to address people's need of 
lifelong learning. Modern distance learning provides such a platform for this and makes lifelong learning come true.

Chinese modern distance learning presents several characteristics such as diversification in education levels, variety in education forms, comprehension in education subjects, modernization in education methods and independence in learning forms. Distinction between formal and informal education, general and vocational education, academic and non-academic education is decreasing. All of these education forms together are developing an education structure including active individuals, intensive communities and linked colleges, creating excellent atmosphere for lifelong learning in the society. Chinese education structure and resources are integrating and building a social education network which allows horizontal flow and free conversion among various education forms. This integrated and connective education network offers systematic service for lifelong learning.

Higher education institutes have advantages in developing distance education with policy support, advanced equipment, new technology and rich faculty. Some institutes have established experimental units of modern distance education and founded their own distance education center. Networking academies are established one after another. Schools of continuing education are expanded. The former stereotyped teaching mode has been replaced by a multi-layer and multifunctional interactive mode. At present, Ministry of Education has authorized 69 higher institutes to establish networking academies with a total enrollment of more than 1,000. Thousands of learning centers and teaching units have been established throughout the country. Higher institutes with those academies have cooperated with more than 20 industries to give professional trainings to millions of people. Meanwhile, through two programs named as Construction and Demonstration of Digital Learning Harbor and Lifelong Learning Society, and Digital Learning Demonstration Center, an array of lifelong learning demonstration centers have been established throughout the country. On 31, July, 2012, Open University of China was set up. It is directly subordinate to Ministry of Education. With the support of modern technology, it launches distance open education and has both degree education and non-degree education, which marks the new stage of Chinese modern distance education.

\section{REFERENCES}

[1] Wan Hailin, "Lifelong Learning under the View of Modern Remote Education Innovation Thinking", Journal of Adult Education College of Hubei University, (4): 1719,2012

[2] Li Wenhui, "Modern Distance Education and Lifelong Learning", Journal of Adult Education College of Hubei University, (3): 9-10, 2011

[3] Gao Yong, "Distance Education in the Systematic Establishment of Lifelong Education", Hebei Academic Journal, (1): 244-247, 2012

[4] ChenXia, "The Study of Modern Remote education and Construction of Lifelong Learning System", Journal of Inner Mongolia Radio and TV University, (4): 64-66, 2011 